\title{
tanding Out vs. Standing Still? Children, Adults S and Janteloven in Thorbjørn Egner's Book People and Robbers of Cardamon Town (Folk og røvere $i$ Kardemomme by)
}

\section{Roxana-Ema Dreve}

Babeș-Bolyai University, Cluj-Napoca, Email: dreveroxana@yahoo.com

\begin{abstract}
Janteloven is a set of ten detailed laws formulated in Aksel Sandemose's book A Fugitive Crosses His Tracks. First intended as a satire of the Scandinavian mentality and of how individuals should integrate themselves in a group, this set of rules is nowadays a cultural phenomenon in Norway that influences not only adults, but also children. The aim of this article is to analyse Thorbjørn Egner's book People and Robbers of Cardamon Town (Folk og røvere i Kardemomme by) -1955, focusing on what children's behaviour could look like, according to the "Jante mentality". We argue that the message presented in the book shows how children's behaviour is influenced by adults' expectations regarding modesty. The self-appreciation or selfdepreciation of the children's inner "I" is therefore related to the difference between standing out and standing still.
\end{abstract}

Rezumat

Keywords: Janteloven; children; behaviour; modesty; voice

CC BY-SA License (https://creativecommons.org/licenses/by-sa/2.0)

\section{Introduction}

In 1936 Aksel Sandemose wrote A Fugitive Crosses His Tracks. Little did he know that his ten laws regarding individual and community behaviour would be referred to as a typical Scandinavian code of modesty. 
The 'Jante mentality' portrays the ways in which people from different society classes should interact with each other. While the rules themselves are a good starting point in analysing the general social dynamics of that period, their ramifications, as both allegory and metaphor ${ }^{1}$, can also be observed in literature. One controversial book tackling this issue, that we will focus on in this article, is Thorbjørn Egner's People and Robbers of Cardamon Town (Folk og røvere i Kardemomme by), from 1955.

\section{Cardamom laws}

Born in 1912, Egner became known in the period after the Second World War2, because of the radio programme Barnetimen for de minste that he established with Anne-Catherine Vestly and Alf Prøysen. The show was a real success. In 2009, the book De tre store: Thorbjørn Egner, Alf Prøysen, Anne-Catherine Vestly, alluding to "de fire store" in Norwegian Literature: Lie, Ibsen, Bjørnson and Kielland, was published, proving that they were indeed loved by the public. Thorbjørn Egner wrote more than 20 books, translated into several languages, and his texts are considered to be a moral pillar for Norwegian children's books.

Many critics say that Egner was a perfectionist. Several of his texts have at least one revised version and People and robbers of Cardamom Town is not an exception. The book appeared in 1955 and then in 1980 with some important changes regarding the songs and the language, issues that will however not make the case of this article ${ }^{3}$. While it is known that the author changed his texts, his reasons are not that obvious. In the article “Da hoa og

\footnotetext{
${ }^{1}$ In his article, 'Janteloven, the antipathy to difference; looking at Danish ideas of equality as sameness', Kusum Gopal mentions that: “[...] I became aware of janteloven, as a philosophy of being, something that is not just an indispensible understanding to etiquette, but a takenfor granted, realized morality - Sittlichkeit - the wider ramifications of which appear to be embodied in the cosmological and political order of the Danish welfare state. As a consequence, it has interested me to observe the powerful connotations 'janteloven' carried both as allegory and as a root metaphor in life of Danes [....]", The Cambridge Journal of Anthropology 24: 3 (2004): 64.

2 Aasta Marie Bjorvand Bjørkøy, 'Fra Pinocchio-småinger til tanntroll. Karius og Baktus fra 1941 til 1958', Edda 2 (2012): 86.

${ }^{3}$ One can read more about this process in Aasta Marie Bjorvand Bjørkøy, 'Da hoa og negermann forsvant. Om revisjon av egner og neger', Nytt norsk tidsskrift 4 (2011): 359.
} 
negermann forsvant. Om revisjon av egner og neger", Aasta Marie Bjorvand Bjørkøy analyses this issue and states that behind these changes there is an ethical choice: "Various considerations and explanations are hidden behind the revision of each song. The revision as well as the censorship can be explained ethically, and the changes are ethically fortunate" (our translation) ${ }^{4}$.

Indeed, writing about contemporary society involves a number of fundamental ethical questions on what the discourse should look like, what elements should be tackled, how social identity is connected to individual identity, the relation to others and so on: "We are confirmed and recognized - or disproved and misunderstood - through dialogue and meeting with others. If we meet adversity, self-understanding must be adjusted. We all try to formulate a viable and attractive identity in stories that present our value in our own eyes and in the eyes of others" (our translation) ${ }^{5}$, says Marianne Egeland.

The texts' path, from inception to revision, is very interesting and explains how society or its definition of what is politically correct can influence one's work. Even if Egner's book is known as a children's book, one can notice that there are rarely direct interactions between adults and children, and that the dialogue is rather placed at the intersection between "me" and "you" (singular and plural).

In the autobiography he wrote in 1984, Thorbjørn Egner mentions that the model for the idyllic, utopic town of Cardamom is actually Fez, in Morocco. But while some critics suggested that the organization of the town and its physical resemblance was Egner's inspiration, Dag Herbjørnsrud emphasizes in the article "Bokomtale som polemikk: En

\footnotetext{
4 “Ulike hensyn og forklaringer skjuler seg bak revisjonen av hver enkelt vise. Revisjonen så vel som sensuren kan forklares etisk, og endringene er etisk heldige". Ibidem: 367.

5 “Vi bekreftes og anerkjennes - eller avkreftes og miskjennes - gjennom dialog og samvær med andre. Møter vi motbør, må selvforståelsen kanskje justeres. Alle prøver vi ut og formulerer en gangbar og attraktiv identitet i fortellinger som tematiserer verdien vår i egne og andres øyne". Marianne Egeland, 'Frihet, likhet og brorskap i Virkelighetslitteraturen', Edda 3 (2015): 229.
} 
kritikk av Jan Eivind Myhre" that Cardamom Town was inspired by the people's way of being, thus by the intellectual resemblance with Fez'

One of these resemblances is with the set of rules Sandemose wrote in the 30's:

1. You shall not believe you are anything.

2. You shall not believe you are as much as us.

3. You shall not believe you are wiser than us.

4. You shall not imagine you are better than us.

5. You shall not believe you know more than us.

6. You shall not believe you are more than us.

7. You shall not believe you are good for anything.

8. You shall not laugh at us.

9. You shall not believe anyone cares about you.

10. You shall not believe you can teach us anything. ${ }^{7}$

The main values expressed by the ten rules are modesty, acceptance, trust, generosity, a humble behaviour, happiness of a well done job, equality among people and last, but not least, as Inga Gentile underlines ${ }^{8}$, the idea that the community is above the individuals. These rules condemn individualistic behaviour and urge for a better connection with the group. While thought as a satire of the contemporary society, the term was seen positively later on and expresses today both a negative and a positive attitude regarding the relationship individuals/ the collective, between standing still, out of fear, and standing out for your own beliefs. Our paper focuses on the influence, both positive and negative of janteloven, as it reveals itself in Thorbjørn Egner's book.

\footnotetext{
${ }^{6}$ Dag Herbjørnsrud, ‘Bokomtale som polemikk: En kritikk av Jan Eivind Myhre', Historisk tidsskrift 86 (2007): 114.

7 Sandemose's rules, adapted from A Fugitive Crosses His Tracks (New York: A.A. Knopf, 1936): 77, quoted in Stephen Richard Trotter, 'Breaking the law of Jante', Myth and Nation 23: 2 ,

https://www.researchgate.net/publication/327885136_Breaking_the_law_of_Jante, consulted on the $13^{\text {th }}$ of April 2020.

${ }^{8}$ Inga Gentile, 'A psychobiological approach to couple therapy and issues of reciprocity: The influence of Janteloven on Norwegian couples', Psychotherapy in Australia 21.
} 


\section{Being equal is being alike?}

It should be stressed that the main narrative in People and Robbers of Cardamon Town is characterized by the principle of equality, which in Norway, as Gullestad, Longva or Marit Ann Barkve suggest, reflects the idea of being alike ${ }^{9}$. While it is true that societies often share common values, the uniqueness of janteloven is that it does not only represent a social norm, but also an individual choice that follows that norm. Addressing this issue, Carsten Levisen writes in "Cultural Semantics and Social Cognition. A Case Study on the Danish Universe of Meaning" that "what makes the Cardamom law slightly different is that one's 'freedom' is highly dependent of 'others'" 10 and that the characters seem to be interconnected. That is why, for a thorough analysis of Egner's book we must not make assumptions as to what we believe janteloven is, but we should instead examine the uniqueness of the set of rules.

If generations of Norwegians only see the positive elements brought by janteloven, explained perhaps by the comparison with the biblical ten commandments 11 , Avant and Knutsen describe janteloven as a "miniature society where the inhabitants are encouraged (or forced) to set the needs of the community before their individual needs"12. The positive and negative connotations of 'Jante mentality' were also discussed by Cornelius Cappelen and Stefan Dahlberg. According to the authors social behaviour critics such as Uslaner, Rothstein, Stolle, Delhey, Newton and Nannestad

\footnotetext{
9 Marit Ann Barkve, 'The Other Mother: Motherhood Tropes in Norwegian Diaspora Literature', Phd thesis, University of Wisconsin, $2018: 3$.

https://www.academia.edu/36203755/The_Other_Mother_Motherhood_Tropes_in_Norwegi an_Diaspora_Literature

${ }^{10}$ Carsten Levisen in 'Cultural Semantics and Social Cognition. A Case Study on the Danish Universe of Meaning', Chiara Gianollo and Daniel Van Olmen eds., Trends in linguistics. Studies and monographs, https://doi.org/10.1515/9783110294651

${ }^{11}$ A deeper research is needed in order to explain this particularity. Sandemose's character, Espen Arnakke says prior to janteloven that "You must not drink alcohol” and that was, as Stephen Richard Trotter underlies it, "the greatest command of Janteloven". Arnakke was raised by a factory worker in a small town, reluctant to his superiors. The entire book is created by his childhood memories that reveal themselves in form of painful flashbacks. The citation was translated by Stephen Richard Trotter, art.cit.: 3.

${ }^{12}$ Gayle Avant and Karen Knutsen, 'Understanding cultural differences: Janteloven and social conformity in Norway', ETC.: A Review of General Semantics 4 (1993): 451 Gale Academic OneFile Select, https://link.gale.com/apps/doc/A14861493/EAIM?u=glasuniEsid=EAIMExid=3123a176. Accessed on the $24^{\text {th }}$ of May 2020.
} 
have analysed these aspects and came to the conclusion "that the levels of generalized trust in the Scandinavian societies are remarkably high"13. In addressing this issue, Stephen Richard Trotter states that janteloven is the expression of society's reluctance of individualism and that the nation is embodied as something "greater than the individual"14, something that surpasses the be-alike feeling and portrays mostly condemnable attitudes. To quote the critic, janteloven "does not define the characteristics of the group, it only defines punishable traits in individuals; it can be superimposed upon other markers of identity"15. Arguably, we could say that children sometimes conform to the rules not because they trust adults, but by fear of getting punished or by boredom (lack of better perspectives), which opens the list of negative effects 'Jante mentality' might have on children.

But is Cardamom Town really bad for children? This was the issue started by the Swedish director Sofia Jupither, who wrote a commentary for the newspaper Aftenposten where she reveals the negative aspects of the novel and the negative influence it has on children. According to her, it seems that "society functions best when everyone is the same, everyone is happy, and otherwise take care of themselves. The greatest misfortune is to be different and not belong to a homogenous group."16 The same idea was analysed by Gayle Avant and Karen Knutsen who argues that "janteloven encourages ethnocentricity and tends to support effort to exclude those who are different" 17 .

At a first look, the negative perception of janteloven can seem puzzling, but Avant and Knutsen manage to demonstrate in their article, "Understanding cultural differences: Janteloven and social conformity in Norway"18 that janteloven had in fact a negative impact on Espen Arnakke. Is that also the case here? People and robbers of Cardamom Town portrays a miniature society governed by janteloven. The description of the idyllic city

\footnotetext{
${ }^{13}$ Cornelius Cappelen and Stefan Dahlberg, 'The Law of Jante and generalized trust', Acta Sociologica: 2, DOI: 10.1177/0001699317717319, 2007.

14 Stephen Richard Trotter, art.cit.: 7.

${ }^{15}$ Ibidem: 8.

${ }^{16}$ Elisabeth Lindsay, 'Cardamom Town 'bad' for children', Newsinenglish.no, https://www.newsinenglish.no/2013/01/09/cardamom-town-bad-for-children/, accessed on the $9^{\text {th }}$ of 2013.

${ }^{17}$ Gayle Avant and Karen Knutsen, art.cit.: 449.

${ }^{18}$ Ibidem.
} 
suggests that the individuals' desires are inferior to community's needs and that every negative aspect is somehow transformed in something positive. Let's take for instance the three robbers that manage not only to become good citizens, but also to serve the law (the fire department). The law that governs policeman Bastian's behaviour is to be friendly and considerate towards the other members of the community: "You must not pester others, but be friendly and considerate; otherwise you may do as you wish"19 No different approach is accepted. Everyone must comply with the rules and do so happily.

In her master thesis, Nigar Latifova depicts several characteristics of Egner's writing: the creation of a new patriotically identity, a new sense of group feeling, the close relationship to the nature, the representation of the woman as a mother, the connection to the society of his time ${ }^{20}$. She underlines the didactic and pedagogical foundation of the book, and the fact that the supremacy of the society, of the group, was necessary after the war, in order to rebuild Norway as a nation. The patriotic feeling needed to be strengthened and one of the means one could use to do so was literature: "One of these elements in his books is a new sense of collectivism and a strong sense of community. According to Thorbjørn Egner, this was important to the nation after the war. First and foremost, it was the very period after the war that made this idea crucial" (our translation) ${ }^{21}$.

As mentioned before, an essential element in Egner's book is the naïve description of the society that establishes a connection with the children as they often lack the maturity to understand complicated adult responsibilities or the ability to stand still and obey. However, giving the social, economic and political problems involved, Egner manages to untighten children into standing out, while not forgetting the importance of a generous, modest and humble society.

\footnotetext{
19 Thorbjørn Egner, People and Robbers of Cardemon Town (Anchorage Press, 1976), translated from Norwegian by Berg and Ramsden : 111.

20 Nigar Latifova, Lesebøker $i$ nasjonsbyggingsprosessen. En sammenlignende analyse av det nasjonale i lesebøker fra Norge og Aserbajdsjan, master thesis, coordinator Elise Seip Tønnessen, Fakultet for humaniora og pedagogikk, Institutt for nordisk språk og litteratur, Agder, 2013: 27.

21 “Et av disse elementene i hans lesebøker er en ny kollektivisme og en sterk fellesskapsfølelse. Ifølge Thorbjørn Egner var dette viktig for nasjonen etter krigen. Først og fremst var det selve den perioden etter krigen som gjorde denne ideen avgjørende.", Nigar Latifova, op.cit: 20.
} 
One of the means to present the rules of the Cardamom society to the children is by using stereotypes and contrast. The contrast between the group and the individual, as well as the not so obvious contrast between the national and the international, or between the negative and the positive, the women and the men 22 could have a didactical purpose. The same goes for the stereotyped community where every gesture has a meaning and every character represents an important social or political institution. Stephen Richard Trotter analysed the relationship between children's behaviour, society and religion in connection to Sandemose's text and concluded that:

"In other words, Sandemose believed people were socialized into Janteloven through religion, whereas the Norwegian nationalist project attempts to socialize children into it through education. With the reproduction of Janteloven through education, we can expect very different results over time in Norwegian society when taking into account changing curricula and educational policies and practices. Having given a brief overview of the context in which Janteloven was implanted, we can now turn to its presumed impact on society by examining its precepts." 23

This is exactly what happens in People and robbers of Cardamom Town. Norman Fairclough's theory about critical discourse analysis describes the relationship between children and society, often related to the understanding of the discourse and the behaviour of the adults. By applying this method, we not only understand social relationships, but also get to deconstruct the social identity of the characters and discover their didactical purpose:

"Texts as elements of social events have causal effects-i.e. they bring about changes. Most immediately, texts can bring about changes in our knowledge (we can learn things from them), our beliefs, our attitudes, values and so forth. [...] Texts can also start wars, or contribute to changes in education, or to changes in industrial relations, and so forth" 24.

\footnotetext{
22 “Egners kvinnesyn var ikke et marginalisert fenomen, han er tvert i mot helt på linje med sin egen samtid" state Buan and Solstad, "Med lesebøker skal landet bygges. Gjennom leseboka skal leseren dannes. Om leserinstansen i Thorbjørn Egners lesebøker 1 og 2", in Dagrun Skjelbred and Bente Aamotsbakken (Red.), Norsk lærebokhistorie - en kultur- og danningshistorie (Oslo, Novus, 2009): 92.

${ }^{23}$ Stephen Richard Trotter, art.cit,: 7.

24 Norman Fairclough, Analysing discourse. Textual analysis for social research (London: Routledge, 2003): 8.
} 
While most of the characters obey janteloven, the robbers and Aunt Sophia are the exceptions. But Aunt Sophia's role is very important since she is the only one to remain angry and bitter even after the robbers reintegrate themselves in society and become nicer persons, important members of the community. The essential role of janteloven and the message the children should remember is presented by this contrast between what the robbers did and the way they were treated. By letting the robbers stand out and fail, even if they steal "what we have to and what we actually need" 25 , the author implemented the rules "You shall not believe you are anything" and "You shall not believe you are wiser than us". The opposite attitude, that of standing still and accepting one's role in the group, could be seen at the end, where the rule "You shall not laugh at us" or "You shall not believe you can teach us anything" take the lead. Kasper becomes the baker's assistant and marries Sophia, Jonathan gets a job as the fire chief, after rescuing the pets from the fire, and Jesper gets a job at the circus.

When the robbers are caught, they are placed in a very clean and confortable house. They are treated equally, they receive good food and people talk nicely to them, even apologizing for misbehaviour or for the prison conditions ("You shall not imagine you are better than us"). Moreover, Jesper is trusted to get out of the confinement in order to feed the lion, thus proclaiming the existence of an idyllic town, where people trust and understand each other ("You shall not believe you are more than us"). Sure, they mildly curse from time to time, but their behaviour is genuinely selfless towards others ${ }^{26}$.

Aunt Sophia, on the other hand, condemns others for being too kind and cheerful and soft. The policeman Bastian, conductor Puddleson and of course, the children, are all attacked with these words: "Oh fiddlesticks o fiddlesticks, I'm angry and I'll frown!/ It's stuff and nonsense everywhere in Cardamom our town./ If only people were like me-everything's be good./ But no one is at all like me-they don't do as they should!"27.

In her article "Janteloven and Social Conformity in Thorbjørn Egner's Literature", Ellen A. Ahlness argues regarding this issue that Aunt Sophia

\footnotetext{
25 Thorbjørn Egner, op.cit.: 95.

${ }^{26}$ When he discovers that something has been stolen from the shop, Bastian says "Neimen Sørensen!", which in the 1950's was a way of expressing indignation.

27 Thorbjørn Egner, op.cit.: 39.
} 
is a breaker of Jante rules because she "considers herself better than others, greater than them, and even considers herself more capable than others at their respective jobs, suggesting that if they were like her they would be better at their duties" 28 .

The contrast is nevertheless essential for the children that understand, as Ellen A. Ahlness says that "[c]ivil treatment is better for all involved than unpleasantness." 29

\section{Conclusion}

In order to conclude we want to emphasize that we analysed this cultural phenomenon called janteloven in Egner's book and observed both a negative and a positive attitude toward it. Therefore, a definitive statement of what janteloven represents is of obvious reasons, not doable. We have, however, discovered that janteloven is a spread mechanism that impacts all classes of society, from the baker, to the policeman, from the children to the robbers, explaining the idea of generalized truth applied to the individual. We could not identify why some aspects were not well received, but we believe that cultural variation and reception played an important part. One can only wonder if the description of such an idyllic town, where everybody stands still and avoid conflicts, was not indeed the factor that allowed Egner to stand out as one of the most important and prominent author of children's books.

\footnotetext{
28 Ellen A. Ahlness, 'Janteloven and Social Conformity in Thorbørn Egner's Literature', Proceedings of the National Conference On Undergraduate Research (NCUR), University of Kentucky, Lexington, KY April 3-5, 2014, https://www.researchgate.net/publication/340661533_Janteloven_and_Social_Conformity_in _Thorbjorn_Egner's_Literature , 551.

${ }^{29}$ Ibidem.
} 


\section{References:}

Ahlness, Ellen A. 'Janteloven and Social Conformity in Thorbørn Egner's Literature'. Proceedings of the National Conference On Undergraduate Research (NCUR), University of Kentucky, Lexington, KY April 3-5, 2014, https:/ / www.researchgate.net/publication/340661533_Janteloven_ and_Social_Conformity_in_Thorbjorn_Egner's_Literature.

Avant, Gayle; Knutsen, Karen. 'Understanding cultural differences: Janteloven and social conformity in Norway'. ETC.: A Review of General Semantics 4 (1993), Gale Academic OneFile Select, https://link.gale.com/apps/doc/A14861493/EAIM?u=glasuni\&sid=EAIM Exid=3123a176, accessed May 24, 2020.

Barkve, Marit Ann. 'The Other Mother: Motherhood Tropes in Norwegian Diaspora Literature'. Phd thesis, University of Wisconsin, 2018, https://www.academia.edu/36203755/The_Other_Mother_Mother hood_Tropes_in_Norwegian_Diaspora_Literature

Buan, Anne-Beathe; Solstad, Trine. 'Med lesebøker skal landet bygges. Gjennom leseboka skal leseren dannes. Om leserinstansen i Thorbjørn Egners lesebøker 1 og 2'. Skjelbred, Dagrun; Aamotsbakken, Bente Red.. Norsk larebokhistorie - en kultur- og danningshistorie. Oslo: Novus, 2009.

Bjorvand Bjørkøy, Aasta Marie. 'Fra Pinocchio-småinger til tanntroll. Karius og Baktus fra 1941 til 1958’. In Edda, nr. 2, 2012, pp. 86-103.

Bjorvand Bjørkøy, Aasta Marie. “Da hoa og negermann forsvant. Om revisjon av egner og neger". Nytt norsk tidsskrift 4 (2011): 359-369.

Cappelen, Cornelius; Dahlberg, Stefan . 'The Law of Jante and generalized trust'. Acta Sociologica (2007): 1-22, DOI: 10.1177/0001699317717319.

Egeland, Marianne. 'Frihet, likhet og brorskap i virkelighetslitteraturen'. Edda 3 (2015): 227-242.

Egner, Thorbjørn. People and Robbers of Cardemon Town. Anchorage Press, 1976. Translated from Norwegian by Berg and Ramsden.

Fairclough, Norman. Analysing discourse. Textual analysis for social research. London: Routledge, 2003. 
Gentile, Inga. 'A psychobiological approach to couple therapy and issues of reciprocity: The influence of Janteloven on Norwegian couples'. Psychotherapy in Australia 21: 42-47.

Gopal, Kusum. 'The Cambridge Journal of Anthropology'. 3 (2004): 64-82.

Herbjørnsrud, Dag. 'Bokomtale som polemikk: En kritikk av Jan Eivind Myhre'. Historisk tidsskrift 86 (2007): 111-115.

Latifova, Nigar. Lesebøker $i$ nasjonsbyggingsprosessen. En sammenlignende analyse av det nasjonale i lesebøker fra Norge og Aserbajdsjan. Master thesis, coordinator Elise Seip Tønnessen. Fakultet for humaniora og pedagogikk, Institutt for nordisk språk og litteratur, Agder, 2013.

Levisen, Carsten. 'Cultural Semantics and Social Cognition. A Case Study on the Danish Universe of Meaning'. In Gianollo, Chiara; Van Olmen, Daniel eds. Trends in linguistics. Studies and monographs, https://doi.org/10.1515/9783110294651.

Lindsay, Elisabeth. 'Cardamom Town 'bad' for children'. Newsinenglish.no. https:/ / www.newsinenglish.no/2013/01/09/cardamom-townbad-for-children/, accessed January 9, 2020.

Sandemose, Axel. A Fugitive Crosses His Tracks. New York: A.A. Knopf, 1936.

Trotter, Stephen Richard. 'Breaking the law of Jante'. Myth and Nation 23, https://www.researchgate.net/publication/327885136_Breaking_t he_law_of_Jante, accessed April 13, 2020. 